\title{
THE EFFECT OF FLOW OF FUNDS UNCERTAINTY ON FINANCIAL DEVELOPMENT IN SOME SELECTED AFRICAN COUNTRIES
}

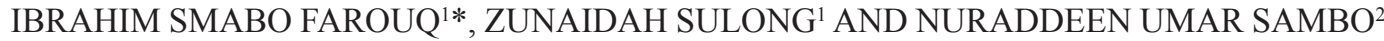 \\ ${ }^{l}$ Faculty of Economics, Universiti Sultan Zainal Abidin, 21030 Kuala Nerus, Terengganu, Malaysia. ${ }^{2}$ World Bank Group, \\ Kano, Nigeria.
}

*Corresponding author: ibrahimumms@gmail.com

Submitted final draft: 10 August $2020 \quad$ Accepted: 25 August $2020 \quad$ http://doi.org/10.46754/jssm.2021.07.020

\begin{abstract}
The purpose of this paper is to analyze the effects of financial globalisation uncertainty on financial development, included in the model are foreign direct investment and economic growth as control variables to avoid the misspecification of variables. This paper analyzed the effects based on the panel data analysis using the Westerlund cointegration method, Pooled Mean Group estimator and Dumitrescu and Hurlin causality test of eight top African economies, from 1970-2018. The result of the co-integration showed a long-run relationship between the variables with and without structural breaks. Also, there exists a bidirectional causality relationship between financial development and financial globalisation uncertainty.
\end{abstract}

Keywords: Financial globalization uncertainty, financial development, economic growth, foreign direct investment, panel westerlund co-integration.

\section{Introduction}

Financial sectors in developing economies such as African countries are making an effort to integrate with the rest of the world to develop their financial system. However, the issue of the global financial crisis was a great wake up call to countries in the world. It highlighted a supervisory rift and crippled banking sector incentives in the overall financial system, and banks were subsequently being uncovered to many risks. This crisis in the financial sector and some of its accomplices have brought new skepticisms for all developing countries like African economies. This paves the way for other researches to provide insights on how these countries can and must prepare their financial sectors to this new world, and also enhance its ability to withstand shocks, coming locally or internationally (Otchere et al., 2017).

Nevertheless, limitation of the unfortunate part of the society and small-scale investors' access to formal credit is still hindering the sustainable economic growth and poverty reduction in the developing economies. Developing the financial sector is essential; researchers are now paying attention to the area because of its importance and about the lack of financial development in developing
African countries when compared, even with, other developing countries. However, despite the extraordinary role played by the financial sector reforms aimed to improve the financial sector development in the various African countries, financial markets in Africa seems to be less developed than financial markets in some other part of the world they are underdeveloped even with the criteria obtained in the developing countries. Also, based on the standards of trading activity and capitalization, most African stock markets are having low liquidity provision (World Bank, 2017).

Consequently, financial sector development in developing African countries are seen to have fluctuations, this instability in the financial sector could be a result of financial globalization uncertainty. This is because, for over twenty years, economies around the globe witnessed massive strikes of instability in their financial sectors. Crises in the banking sector seem more common that there were even financial crises that had an overwhelming effect on some economies around the globe. This financial instability has become a severe problem for developing economies such as these selected African countries under this study. 
However, this problem of instability for the financial sector development even in the top African economies is of great concern, and that calls for the need to address the problem. This is because financial contagions keep economies' financial sectors integrated around the globe and, at the same time, brought about uncertainty.

Therefore, a financial problem in one country could affect other economies of the world; as seen during global financial crises, it was a problem that started in America but as a result of global financial integration, it negatively affected most of the economies around the globe. Conversely, most of the leading African countries are characterised by low investment and inadequate financing, and these led to the immense fall of gross domestic productivity (GDP) and desperate effort to attract more investors so that foreign capital and investments (FDI) can flow in and address the problems of financing and business ventures. Despite the effort and considering that foreign capital flows have increased by 15 times in Africa from 1990 to 2017 , they still account for less than $3 \%$ of world inflows (see figure 1) (Benfratello, et al. 2019).
The location factors for investment into Africa may be different Asiedu (2002) and investors still perceive Africa as a risky investment destination. Millennium Development Goals (MDGs) has recorded that severe poverty has been going down around the globe, only leaving Africa in (World Bank, 2015).

Nevertheless, there have been a few existing empirical studies that examined the long-run relationship between financial globalization and financial development. However they have still not come to a complete consensus in respect to the relationships (Makoni \& Lindelwa, 2016; Lawal et al., 2016; Asongu et al., 2017; Saini \& Singhania, 2018; Lee et al., 2019).

Furthermore, with the emergence of curiosity in policymaking and research, additional research will be of great importance. It is considering the different results in both the theoretical and empirical levels, that bring about background motivation for this research. Thus, this study examined the co-integration that exist between financial globalization uncertainty and financial development with evidence from top eight developing African countries for a period 1970 to 2018.

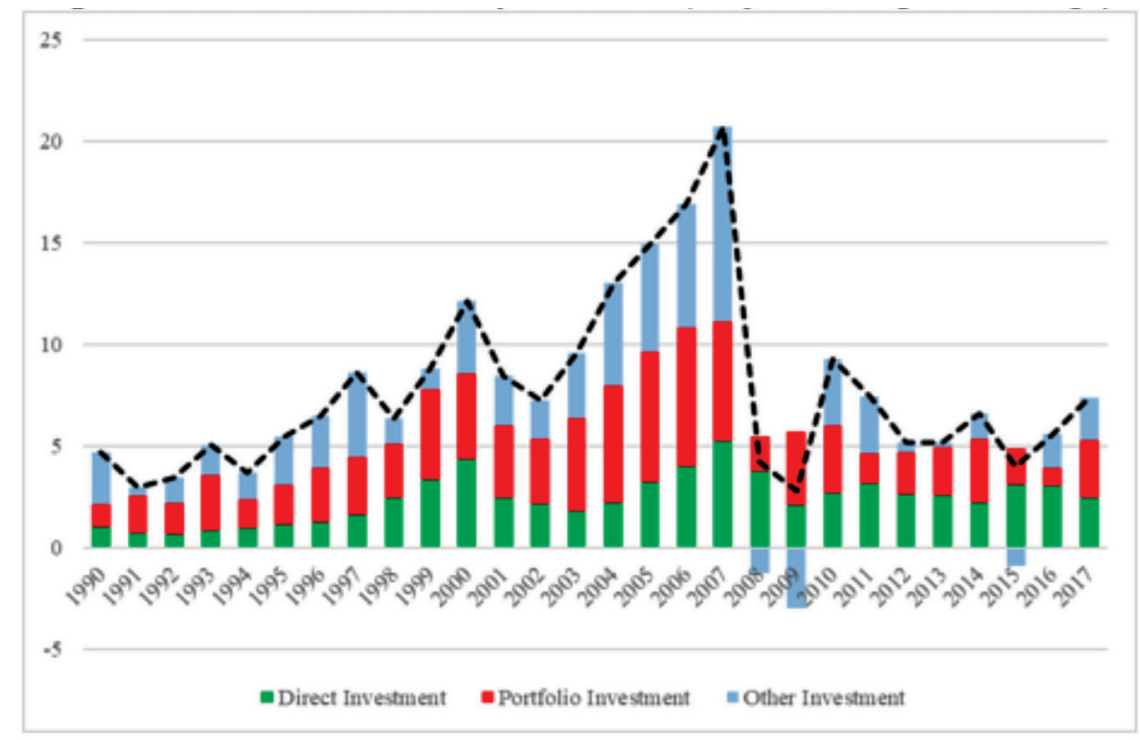

Figure 1: Evolution of Global Capital Inflows (\% of GDP, weighted average) 
Therefore, this paper focuses on the top eight developing African economies as evidence, covering 1970 down to 2018 and some new generation techniques are applied to fill in the gap left by previous studies, which to the best of my knowledge is the first to sample top eight African economies in examining the co-integration between financial globalization uncertainty and financial development.

In addition, as the study used the period between 1970 - 2018, one of the major contributions of this paper is considering the effect of World financial crisis of 2007-2008 on financial development. The driving factor of this break is linking the role of most leading African countries' financial sector with the rest of the world, even though financial sectors in Africa are said to have limited integration with the global market (BIS, 2019).

Meanwhile, the present study analyzes the impact of financial globalisation uncertainty on financial development in eight leading African economies. Furthermore, introduced to support the model are control variables such as foreign direct investment and economic growth to avoid misspecification of variables.

This paper contributes to the existing studies in various ways. It examines the impact of financial globalisation uncertainty on financial development. Also, the study checks for the effect of the global financial crises of 2007-2008. The included control variables in the model for the study may have a substantial impact on the development of the financial sector, more especially for these eight leading African countries under the current study.

Nevertheless, the scope of current study encompasses eight leading African countries, mainly, Egypt, Nigeria, South Africa, Algeria, Morocco, Ethiopia, Ghana, and Kenya, for the period running from 1970 to 2018, and makes available vital policy recommendations for these economies and also to the rest developing countries in Africa. Econometric methods are employed in the study for empirical analysis.

Hence, going forward, the study is arranged as; Part 2 relevant past literatures are discussed. Part 3 highlighted the methods and theory this study lies on. Part 4 comprises the empirical findings and subsequent discussion. Part 5 gives conclusions and policy implications and suggestions.

\section{Literature Review}

This paper reviewed mostly financial liberalisation and globalisation studies, as a direct study concerning financial globalisation uncertainty is somewhat limited, as such this paper focused on reviewing mostly relevant studies that have to do with this research. Meanwhile, several studies argued that globalisation instigates world instability in the financial sector, which has significant negativity on development feedback, while some believe that the concept is a kind of a secret plan to extend the advantages of international trade in goods to transact in assets.

This argument is appropriate to Africa within the scheme of financial globalisation in financial development feedback in these four ways: the current world trends of poverty; liquidity surpluses in the African financial sectors; alarming need of external investors for Africa's projects financing and literature gap in examining the effect of globalisation on the continent's financial development.

\section{Financial Globalisation Uncertainty and Financial Development}

Asongu et al. (2017), in their 53 African countries' study, found that no significant effect between financial globalisation uncertainty and financial system deposits, money supply, and financial size. However, there was an increase in the banking system efficiency and financial system activity as a result of uncertainty. Besides, the positive impact is due to the uncertainty levels. This is because uncertainty in foreign capital flows might be a camouflaged advantage to the local financial development, more especially in times of considerable surplus liquidity in the African financial sector. 
Similarly, Maasoumi et al. (2015) explored the phenomenon with the evidence from African countries too and established that studies of before and after analysis indicated that financial liberalisation has a negative relationship with income inequality, thereby making tremendous progress in income inequality to decline explicitly in the short run.

Moreover, the same African countries, Personal et al. (2017) documented that financial development and financial liberalisation were having positive effects on financial instability. Further findings also indicated that economic growth decreases financial instability, and the level of reduction is enormous in the pre-liberalisation period as against the postliberalisation period.

Whereas, Hosseininasab et al. (2016) has investigated the impact of trade and financial liberalisation on financial development given evidence from countries in the Middle East and North Africa (MENA) region . The empirical findings suggested that trade liberalisation and financial liberalisation have a particular effect on financial development; this could be a result of the inefficiency of the financial sector to provide sufficient financial resources.

However, when the liberalisation of the two is used simultaneously, there was a negative effect on financial development in the region. However, Pervez \& Nasreen (2017), in their study from the middle-income countries, showed that a bidirectional causality existed between financial development and financial liberalization.

Also, there was a long-run linkage between financial development, institutional quality, financial liberalisation and auxiliary variables in MICs. Further findings demonstrated that financial development is determined by institutional quality measures, financial liberalisation, economic growth and trade openness strategies.

Conversely, Fetai (2015) investigated the impact of financial development and financial integration on economic growth using the data set of 89 developed and countries in transition and found that financial development and financial integration had a positive impact on economic growth for economies in transition, unlike in developed economies. Moreover, the impacts are incredibly non-linear. The impact may disappear as financial development gets to the level of the developed nations.

Also, financial integration might not have a positive impact on economic growth because its impact depends on the development of the local financial sector, quality of institutions and macroeconomic stability. However, the Indian study by Zare \& Haghighat (2017) found that long-run and short-run relationships existed between globalisation in all of its kind (social, political and economic) and all of the measures. Also, population density and economic growth both enhanced financial development. Moreover, institutional quality is not appropriate for financial development in India, and there was a feedback impact between inflation and financial development.

\section{Economic Growth and Financial Development}

Ananzeh and Othman (2019)(VECM recorded a long-run relationship between economic growth and financial development. As causality test showed a unidirectional causality from financial development to GDP. Also, additional supportive findings of Lawal et al. (2016); Achamoh and Baye (2016); Kassi et al. (2017) as they all used a single developing economy.

Meanwhile, Williams (2018) first central finding indicated that financial development was not a significant factor leading to economic growth. The evidence suggested however that effective government policies have a significant role that brings about economic growth. Whereas the second finding also showed that economic growth does not affect financial development.

These two main findings indicated no finance-growth relationship. These empirical results violated the finance theory of Schumpeter (1911) and those findings supporting the finance-growth nexus such as Li et al. (2015), 
Lawal et al. (2016), and Achamoh and Baye (2016) to mention but few. Even though Kouki (2018) used the same method and found a longrun relationship between economic growth and financial development. Hence, the period and countries used differs.

\section{Foreign Direct Investment and Financial Development}

The work of Masamba (2017) concluded that the causal relationship between foreign direct investment (FDI), inflation, trade openness, per capita gross domestic product (GDP) and the banking sector liquidity existed.

Moreover, while no causality recorded between foreign direct investment and banks' lending to the private sector in the long run. Hence, bank liquidity had the most significant effect on foreign direct investment in the short run. That significant positive relationship between banking sector liquidity and foreign direct investment revealed that in South Africa, FDI was not only concerned about the size of the market but also the liquidity level. The need for concentration in the banking sector for liquidity improvement.

However, Aibai et al. (2019) revealed that FDI could reasonably influence the development of the financial sector as the study uses 50 Belt and Road Initiative (BRI) countries, especially the advancement of financial markets. FDI was found to be a significant driver of financial deepening for economies with efficient institutions.

Similarly, Muranovic (2018) using 26 developing countries, found that domestic financial markets are the vital and sensitive precondition for FDI to determine a host country's growth positively. Boateng et al. (2017) used 16 sub-Saharan African countries and concluded that financial development accompanied FDI inflows to boost domestic ventures in SSA.

\section{Data}

This paper used panel data spanning the period 1970 to 2018 on eight African economies, namely: Egypt, Nigeria, South Africa, Algeria, Morocco, Ethiopia, Ghana, and Kenya. These countries were selected based on the data available on all the variables this study was interested in. In coming up with the proxy of financial development PCA (principal component analysis) technique, which requires a statistical way of transforming certain cointegrated variables to a smaller figures of uncorrelated digits was used, financial globalisation uncertainty was also measured as the standard error corresponding to the first auto-regressive process of Net FDI inflows.

Consistent with the work of Asongu \& De Moor (2015), Moreover, the study used net BOP current USD Dollar for FDI and GDP annual percentage for economic growth. Hence, the data is generated from World Development Indicators (WDI, 2019) as well as the International Monetary Fund (2019).

\section{Empirical Model}

The analysis of this study will build on the endogenous growth model. Many researchers and academies commonly used it (Rateiwa \& Aziakpono, 2017; Sainz-fernandez et al., 2018; Tsaurai, 2018). Considering the fact that finance theory lacks an explicit model (Ndako, 2010), we therefore build on the endogenous growth model of Romer (1986) and Lucas (1988).

$x_{i t}=F\left(K_{i t}+L_{i t}+A\right)^{l-\partial}$

As $x_{i t}$ is the GDP, $K_{i t}$ stands for capital symbolizes $L_{i t}$ labour; while $G_{i}$ represented technology, and 'it' denotes economies and period respectively. This study will expand the equation (1) earlier stated above, thereby introducing the variables of the present study we have:

$$
\begin{aligned}
& L_{N F D_{i t}}=(1-\partial)_{y l l} L N F G U_{i t}+(1-\partial)_{y l i} L N F G D P_{i t} \\
& +(1-\partial)_{y l l} L N F G D I_{i t}+u_{i t}
\end{aligned}
$$




\begin{tabular}{lllll}
\hline \multicolumn{1}{c}{ Variables } & Symbol & \multicolumn{1}{c}{ Measure } & $\begin{array}{c}\text { Expected } \\
\text { sign }\end{array}$ & \multicolumn{1}{c}{ Economic implication } \\
\hline $\begin{array}{l}\text { Financial } \\
\text { development }\end{array}$ & FD & PCA & N/A & + \\
\hline $\begin{array}{l}\text { Financial } \\
\text { globalisation } \\
\text { uncertainty }\end{array}$ & FGU & $\begin{array}{l}\text { Standard error } \\
\text { corresponding to the first } \\
\text { auto-regressive process of } \\
\text { Net FDI inflows }\end{array}$ & Positive & $\begin{array}{l}\text { This uncertainty forces the } \\
\text { economy to expand its financial } \\
\text { institutions to withstand the risk of } \\
\text { capital shortage. }\end{array}$ \\
\hline $\begin{array}{l}\text { Economic } \\
\text { growth }\end{array}$ & GDP & GDP US Dollar & Positive & $\begin{array}{l}\text { Growth increases economic } \\
\text { and banking activities, thereby } \\
\text { increasing demand for financial }\end{array}$ \\
& & & & $\begin{array}{l}\text { services, which will subsequently } \\
\text { trigger the financial sector to } \\
\text { develop to meet up with the } \\
\text { demand of the growth. }\end{array}$ \\
\hline $\begin{array}{l}\text { Foreign direct } \\
\text { investment }\end{array}$ & FDI & Net BOP current USD & Positive & $\begin{array}{l}\text { More foreign investors mean more } \\
\text { investments, in return, higher } \\
\text { financial transactions, which will } \\
\text { demand more financial instruments. }\end{array}$ \\
& & Dollar & & Hence, expanding financial sector. \\
\hline
\end{tabular}

\section{Westerlund Panel Co-integration}

This paper employed a panel co-integration technique developed by Westerlund, as this test takes care of heteroskedastic and serially correlated error, unit-specific time trends, and cross-sectional dependence. However, it has the capacity to accommodate known structural breaks while testing co-integration in both intercept and slope. This co-integration is more advantageous than the first-generation cointegration techniques. In the sense that it goes with the LM stationarity method. Thus, consider the following models:

$y_{t}=\gamma_{i}+\partial_{i} t+\tau_{i} D_{i t}+x_{i t}^{\prime} \varphi_{i}+\left(D_{i t} \varphi_{i t}\right)^{\prime} \omega_{i}+q_{i t}$

$x_{t}=x_{i t-1}+m_{t}$

Where $i=1, \ldots, N$ and $t=1, \ldots, T$ represent the period and panel data. The k-dimensional vector $x_{i t}$ denotes the independent variables and cited as stochastic. The scalar break dummy represented by $D_{i t}$ such that $D_{i t}=1$ if $t>T_{i}$ and zero otherwise. Also, $\gamma_{i}$ and $\varphi_{i}$ denotes the cross-unit-specific intercept and slope coeffcient before the break, while $\tau_{i}$ and $\omega_{i}$ represent the change in these parameters after the break. $m_{t}$
Furthermore, $I$ represented as an error term with mean zero and independent across. To generate disturbance term $q_{i t}$, the following are models that allow cross-sectional dependence through unobserved common factors.

$m_{t}=\tau_{i}^{\prime} M_{i}+q_{i t}$

$M_{j i}=\gamma_{i} M_{j i-1}+\mu_{j i}$

$\beta_{i}(L) \Delta q_{i t}=\beta_{i} q_{i t-1}+e_{i t}$

Where $\beta_{i}(L)=1-\sum_{j=1}^{p i} \beta_{i} L^{j}$ is the indeterminate coefficient in the lag. $L, M_{i}$ is an r-dimensional vector of unobservable common factors $M_{j i}$ with $j=1, \ldots, \mathrm{r}$, and $\tau_{i} \mathrm{~s}$ the corresponding vector of factor loading parameters. The error term is independent of and for all is mean zero and independent among both $\mathrm{i}$ and $\mathrm{t}$. Under the assumption that $p j<1$ for all $j$, it is assumed that $M_{i}$ is stationary involving the order of integration of the composite regression error $q_{i t}$ depends only on the level of integration of the individual disturbance term $\mu_{i t}$. However, the relationship in Equation (13) is co-integrated if $\beta_{i}<0$ and spurious if $\beta_{i}=0.8$. 
For the test, under the LM principle, the score vector has zero mean when evaluated at the vector of true parameters under the null. Therefore, Westerlund and Edgerton (2008) consider the pooled log-likelihood function below:

$$
\log (L)=\alpha-\frac{1}{2} \sum_{i=1}^{N}\left(T \log \left(\rho_{i}^{2}\right)-\frac{1}{\rho_{i}^{2}} \sum_{i=1}^{T} e_{i t}^{2}\right)
$$

Their test can be derived by first concentrating the log-likelihood function on $\rho_{i}^{2}$ and then evaluating the resulting score at the restricted maximum likelihood estimates.

Let $\sigma_{i}^{2}=\frac{1}{T} \sum_{i=1}^{T} e_{i t}^{2}, \quad$ then the score contribution for unit $\mathrm{i}$ is given by

$\frac{\partial \log (L)}{\partial \beta_{i}}=\frac{1}{\hat{\rho}_{i t}^{2}} \sum_{i=2}^{T}\left(\Delta \hat{R}_{i t}-\Delta \widehat{R}_{i}\right)\left(\hat{R}_{i t}-\hat{R}_{i}\right)$

Where $\hat{R}_{i t}$ is an absolute residual defined below, while $\Delta \hat{R}_{i}$ and $\hat{R}_{i}$ are the mean values of $\Delta \hat{R}_{i t}$ and $\hat{R}_{i t}$, respectively. The score vector is proportional to the numerator of the leastsquares estimate of $\beta_{i}$ in the regression.

$\Delta \hat{R}_{i t}=\alpha+\beta_{i} \hat{R}_{i t-1}+e_{i t}$

It follows that a test of the null hypothesis of no co-integration for cross-section unit I can be formulated equivalently as a zero-slope restriction in Equation (21), which can be tested using either, the least-squares estimate of $\beta_{i}$ or its t-ratio. Therefore, by considering the form of the log-likelihood function, a panel test of $H_{0} v s . H_{1}$ can be constructed by using the cross-sectional sum of these statistics for each i. In the presence of cross-sectional dependence, the variable $\hat{S}_{i t}$ can be computed as:

$$
\Delta \widehat{R}_{i t}=\alpha+\beta_{i} \hat{R}_{i t-1}+\sum_{j=1}^{p i} \delta_{i} \hat{R}_{i t-j}+e_{i t}
$$

Where

$$
\begin{aligned}
\hat{R}_{i t}= & y_{t}-\hat{\gamma}_{i}+\hat{\delta}_{i} t+\hat{\rho}_{i} D_{i t}+x_{i t}^{\prime} \hat{\varphi}_{i}+ \\
& \left(D_{i t} \varphi_{i t}\right)^{\prime} \widehat{\omega}_{i}+\hat{\beta}_{i} \hat{q}_{i t}
\end{aligned}
$$

$\hat{q}_{i t}$ represent the principal component $\Delta \hat{q}$ of $\Delta q$ for dependency across the section, common factors are created, also to make it productive, by augmenting regression it will clear autocorrelation. For $\mathrm{t}=2,3, \ldots \ldots$. T with $\widehat{R}_{i t}$ $=0$.This indicated that the restricted maximum likelihood estimate of $\hat{\gamma}_{i}=y_{t}-\widehat{\omega}_{i}-\hat{\delta}_{i} t-$ $\hat{\rho}_{i} D_{i t}-x_{i t}^{\prime} \hat{\varphi}_{i}-\left(D_{i t} \varphi_{i t}\right)^{\prime} \widehat{\omega}_{i}$ and OLS regression can be used to get the remaining parameters estimates of the equation

$$
\begin{aligned}
\Delta y_{t}= & \widehat{\omega}_{i}+\hat{\rho}_{i} \Delta D_{i t}- \\
& \Delta x_{i t}^{\prime} \hat{\varphi}_{i}-\Delta\left(D_{i t} \varphi_{i t}\right)^{\prime} \hat{\sigma}_{i}+\Delta q_{i t} .
\end{aligned}
$$

They as well introduced LM statistics thereby testing alternate and hull

$H_{G}=\frac{1}{N} \sum_{I=1}^{N} Z \partial_{i j} \frac{\hat{\delta}_{i}}{\widehat{\omega}_{i}}$

$H_{P}=\frac{1}{N} \sum_{i=1}^{N} \frac{1}{R_{e}}$

Where $\hat{\delta}_{i}$ refers to the least square estimate of $\partial_{i}, \quad \widehat{\omega}_{i}^{2}=\frac{1}{Q} \sum_{i=1}^{Q}\left(\hat{R}_{i t}\right)^{2}$ and $\hat{\delta}_{i}^{2}=$ $\frac{1}{o-1} \sum_{j=-r}^{R}\left(1-\frac{j}{R+1}\right) \sum_{t=j+1}^{Q} \Delta \widehat{R}_{i t} \Delta \widehat{R}_{i t-j}$

where $\mathrm{R}$ determines how many lagged covariance of to be estimated in the variables. $H_{0}: \alpha i=0$ stands for the panel tests a null hypothesis and alternative hypothesis represented by $H_{1}: \alpha i=<0$ for all $i . H_{G}$ and $H_{P}$ Denotes statistics of the group.

\section{Long-run and Short-run Estimates}

Having seen the co-integration among variables, the step next to it is that of estimating the longrun elasticities. Supposing this study assumes the panel to be homogenous, then we can apply panel regression methods like generalized methods of the moment, pooled OLS, and the rest. Meanwhile, the assumption that financial development and financial globalisation uncertainty is homogenous across all the eight selected leading African economies is not realistic. 
Furthermore, the countries selected for this study differ in terms of their cultural, economic and social norms. Therefore, the selection of methods that can accommodate this heterogeneity is of paramount importance. As such the study employed pooled mean group
(PMG) estimators by Pesaran et al., (1999). Considering complex slope coefficients among economies, these estimators at the same time take into account the cross-sectional dependence of the variables across the nations. The Pooled Mean Group Model, including the long-run relationship between variables, may follow as:

$$
\begin{aligned}
\Delta L F D_{i t}=\beta_{1}+ & \gamma T+\sum_{j=1}^{p-1} \partial_{i j} \Delta L F D_{i t-j}+\sum_{1=0}^{q-1} \gamma_{i j} \Delta L F G U_{i j-1} \\
& +\sum_{1=0}^{r-1} \delta_{i j} \Delta L F D I_{i j-1}+\sum_{1=0}^{s-1} \varphi_{i j} \Delta L E G_{i j-1}+\pi_{1} L F D_{i j-1}+\pi_{2} L F G U_{i j-1} \\
& +\pi_{3} L F D I_{i j-1}+\pi_{4} L E G_{i j-1}+\mu_{1 i t}+\varepsilon_{1 i t}
\end{aligned}
$$

Where: $\triangle$ is the first difference driver, and $L F D$, $L F G U, L F D I, L E G$ are the four variables to be used in this study. $\beta$ refers to constant, the short-run and long-run coefficients represent $\partial_{i j}$, $\gamma_{i j}, \delta_{i j} \varphi_{i j}$ and $\vartheta_{i j}$ and $\pi_{1}, \pi_{2} \pi_{3} \pi_{4}$ accordingly. $p$, $q, r$ and $s$ denotes the maximum lags, $\varepsilon_{1 i t}$ is the error term.

\section{Dumitrescu and Hurlin (DH, 2012)}

In analysing the causality relationship between the variables, this paper considers Dumitrescu

and Hurlin (DH, 2012) panel causality test. It is a kind of non-causality test granted by Granger (1969). Goes well with fixed coefficient models and heterogeneous data. It has the null hypothesis of non-causality relationship.

However, the alternative has two subgroups of cross-sectional: one account from $\mathrm{x}$ to $\mathrm{y}$ causality relationship and the other part of the group for which shows no causality relationship from $\mathrm{x}$ to $\mathrm{y}$. The Dumitrescu and Hurlin independent panel Granger causality test estimates are:

$$
\begin{aligned}
\Delta L F D_{i, t}=\beta_{i} & +\sum_{k=1}^{K} \partial_{i}^{(k)} \Delta L F D_{i, t-k}+\sum_{k=1}^{K} \gamma_{i}^{(k)} \Delta L F G U_{i, t-k}+\sum_{k=1}^{K} \delta_{i}^{(k)} \Delta L F D I_{i, t-k} \\
& +\sum_{k=1}^{K} \theta_{i}^{(k)} \Delta L E G_{i, t-k}+\varepsilon_{i, t}
\end{aligned}
$$

Where constant is represented by $\beta_{i}$. Moreover, $K$ denotes constant lag orders. This grant $\partial_{i}^{(k)}, \gamma_{i}^{(k)}, \delta_{i}^{(k}$ and $\theta_{i}^{(k)}$. As coefficients of slope and autoregressive parameters to vary among the groups. The model uses a fixed special effect and fixed coefficient model. The probability value and F-statistics value, which depicts whether or not to reject the null hypothesis, account for the existence of causality or not, respectively.

\section{Results and Discussion}

\section{Descriptive Statistics and Correlation Analysis}

Tables 1 and 2 below shows the descriptive statistics and correlation analysis for the eight leading African countries. The variables for this research are; Financial development (FD), Financial globalisation uncertainty (FGU), Foreign direct investment (FDI), and Economic Growth (GDP). The Kurtosis and Skewness values depict asymmetric data distribution. 
However, should the Kurtosis and Skewness values show 0 and three respectively, that means the data is usually distributed. Jarque-Bera Statistics coefficients of the variables revealed that the average frequency distributions.

\section{Result of Cross-section Dependence Test}

This paper uses a method of analysis that handles the cross-sectional dependency problem. Therefore, the study employed two independent cross-sectional tests developed by Pesaran (2007) and Friedman (1937) to test if the panel data are cross-sectional independent or not. Pesaran (2007) came up with a test statistic located on the pair-wise average correlation coefficients of the residuals acquired from an autoregressive
(AR) model. The null hypothesis is crosssection independence. Table 3 below report the findings of the cross-sectional dependency tests, and in line with these correlations, it can be seen that financial development, financial globalisation uncertainty, economic growth, and foreign direct investment are strongly dependent on each other in these African economies under this study.

Moreover, the values of the probability highlighted that the null hypothesis of independence is firmly dropped at a $1 \%$ significance level, as such cross-sectional dependence has to be acknowledged when estimating the statistics of this panel data to avoid bias results.

Table 1: African Summary of descriptive statistics

\begin{tabular}{|c|c|c|c|c|c|}
\hline Variables & Mean & $\begin{array}{l}\text { Standard } \\
\text { deviation }\end{array}$ & Skewness & Kurtosis & $\begin{array}{c}\text { Jarque- } \\
\text { Bera }\end{array}$ \\
\hline $\mathrm{LFD}_{\text {it }}$ & 2.743 & 0.736 & -0.995 & 6.134 & $\begin{array}{r}22.232 * \\
(0.000)\end{array}$ \\
\hline $\operatorname{LFGU}_{i t}$ & 19.511 & 1.389 & -0.279 & 2.726 & $\begin{array}{l}6.331 * * \\
(0.0421)\end{array}$ \\
\hline $\mathrm{LEG}_{\mathrm{it}}$ & 1.382 & 0.890 & -1.715 & 9.031 & $\begin{array}{l}78.446 \\
(0.000)\end{array}$ \\
\hline LFDI $_{i t}$ & 18.466 & 4.193 & -3.329 & 18.982 & $\begin{array}{l}48.431 \\
(0.000)\end{array}$ \\
\hline
\end{tabular}

Table 2: Correlation matrix

\begin{tabular}{ccccc}
\hline Variables & LFD $_{i t}$ & LFGU $_{\text {it }}$ & LFDI $_{i t}$ & LEG $_{\text {it }}$ \\
\hline LFD $_{\text {it }}$ & $\mathbf{1 . 0 0 0}$ & & \\
& & & \\
LFGU $_{\text {it }}$ & $-0.100^{* *}$ & $\mathbf{1 . 0 0 0}$ \\
& $(0.0468)$ & & \\
& & & & \\
LFDI $_{\text {it }}$ & $0.028^{* *}$ & $0.420^{*}$ & $\mathbf{1 . 0 0 0}$ & \\
& $(0.576)$ & $(0.000)$ & & \\
& & & & \\
LEG $_{\text {it }}$ & $0.162^{*}$ & $0.115^{* *}$ & $0.198^{*}$ & $\mathbf{1 . 0 0 0}$ \\
& $(0.001)$ & $(0.022)$ & $(0.000)$ & \\
\hline
\end{tabular}

Notes: $* *$ and $*$ denotes in $5 \%$ and $1 \%$ levels. the $p$-values are in the brackets 
Table 3: Cross-Sectional dependence test

\begin{tabular}{lcc}
\hline & \multicolumn{2}{c}{ Leading African Economies } \\
\hline \multicolumn{1}{c}{ Variables } & Pesaran's CD test & Breush-Pagan (LM) test \\
\hline LFD $_{\text {it }}$ & $4.684^{*}$ & $72.213^{*}$ \\
& $(0.000)$ & $(0.000)$ \\
& & \\
LFGU $_{i t}$ & $18.868^{*}$ & $504.626^{*}$ \\
& $(0.000)$ & $(0.000)$ \\
LEG $_{\text {it }}$ & $2.508^{*}$ & $67.878^{*}$ \\
& $(0.000)$ & $(0.000)$ \\
LFDI $_{i t}$ & $9.690^{*}$ & $133.345^{*}$ \\
& $(0.000)$ & $(0.000)$ \\
\hline
\end{tabular}

Note: $* *$ and $*$ denotes in $5 \%$ and $1 \%$ levels. the $p$-values are in the brackets.

\section{Result of Panel Unit Root Test}

To examine the existence of stochastic nonstationary in the series, this study uses the first generation panel unit root tests which neglect the presence of cross-sectional dependence but were commonly used in the panel data studies. Specifically, Levin et al. (2002) (LLC) test for a standard unit root process. We also used the Madalla and $\mathrm{Wu}$ test, which combines the significance values while testing for stationarity. If the T-tests are frequent, the level of significance is uniform and independent $(0,1)$. All unit root tests assume non-stationarity under the null hypothesis.
However, these tests assume cross-section independence, therefore, to take into account cross-section dependence to have a more reliable conclusion. This paper employed the second generation unit root panel data test as developed by Pesaran (2007). This test analyses the unit root, thereby accommodating cross-sectional dependence. Cross-Sectional ImPesaran (2007) concentrates on the origin of the universal determinants that cause the panel data crosscorrelations to gain the series unit root.

Moreover, as presented in table 4, the results of Levin-Lin Chu, Madalla, and $\mathrm{Wu}$, and finally, the CIPS unit root tests revealed the rejection of the null hypothesis, only except

Table 4: Emerging African Panel Unit Root Test

\begin{tabular}{lcccccc}
\hline Variables & \multicolumn{2}{c}{ LLC. } & \multicolumn{2}{c}{ Madalla and Wu } & \multicolumn{2}{c}{ CIPS } \\
\cline { 2 - 7 } & At level & $\begin{array}{l}\text { At first } \\
\text { different }\end{array}$ & At level & $\begin{array}{l}\text { At the first } \\
\text { diff }\end{array}$ & At level & $\begin{array}{c}\text { At first } \\
\text { different }\end{array}$ \\
\hline LFD $_{\text {it }}$ & $-1.405^{* *}$ & $-5.565^{*}$ & $74.041^{*}$ & $163.760^{*}$ & -2.611 & -6.395 \\
& $(0.079)$ & $(0.000)$ & $(0.000)$ & $(0.000)$ & $(-3.06)^{*}$ & $(-3.06)^{*}$ \\
LFGU $_{i t}$ & -2.637 & $-9.030^{*}$ & $40.543^{*}$ & $212.930^{*}$ & -3.705 & -5.545 \\
& $(0.004)$ & $(0.000)$ & $(0.001)$ & $(0.000)$ & $(-3.06)^{*}$ & $(-3.06)^{*}$ \\
LFDI $_{\text {it }}$ & $-4.578^{*}$ & $-15.475^{*}$ & $86.760^{*}$ & $347.215^{*}$ & -5.415 & -6.395 \\
& $(0.000)$ & $(0.000)$ & $(0.000)$ & $(0.000)$ & $(-3.06)^{*}$ & $(-3.06)^{*}$ \\
$\mathrm{LEG}_{\mathrm{it}}$ & $-3.057^{*}$ & $-11.656^{*}$ & $68.695^{*}$ & $272.953^{*}$ & -4.303 & -6.224 \\
& $(0.001)$ & $(0.000)$ & $(0.000)$ & $(0.000)$ & $(-3.06)^{*}$ & $(-3.06)^{*}$ \\
\hline
\end{tabular}

Note: $* *$ and $*$ denotes in $5 \%$ and $1 \%$ levels. the $p$-values are in the brackets, but as for the CIPS, those in brackets represent the critical values. 
financial development in both LLC and CIPS at level, but rejected the null hypothesis at first difference. However, the rest of the variables under this study, namely; financial globalisation uncertainty, economic growth and foreign direct investment are all having mixed stationarity, with a strongly significant level at $1 \%$.

\section{Co-integration Test Analysis}

To examine the impact of financial globalisation uncertainty, economic growth, and foreign direct investment in eight leading African countries. This study further deployed a second-generation approach of co-integration, namely Westerlund \& Edgerton (2008) test, to test the long-run associations between the variables. The most advantageous part of this process is to analyse the variables co-direction with the absence of endogeneity.

Furthermore, Table 5 and 6 depicts the long-run relationship test results. Both with and without breaks, a rejection of the null hypothesis (no cointegration) at constant and $1 \%$ level of significance, which shows it firmly rejects the null hypothesis and accept the alternate hypothesis as regards the presence of co-integration among variables under this study. Similarly, at constant and trend, all the four statistics revealed rejection of the null hypothesis and firm acceptance of co-integration among the variables, since the probability value is significant at $1 \%$. Hence, there are longrun linkages between financial globalisation uncertainty, economic growth, foreign direct investment, and financial development.

Conversely, while estimating co-integration considering global financial crises of 2007 down to 2018 , the results revealed that at a constant level, there was a strong significant long-run relationship among variables with a $1 \%$ level of significance. Whereas, at constant and trend, the group means statistic rejects the null hypothesis at a 5\% significant level, while the panel statistic rejects the null hypothesis at a $1 \%$ level of significance. Thus, financial globalisation uncertainty, economic growth, foreign direct investment and financial development have a long-run relationship even with the event of global financial crises.

Table 5: Summary Results of Heterogeneous Co-Integration Tests Without breaks

\begin{tabular}{|c|c|c|c|c|c|}
\hline \multirow[t]{2}{*}{ Test type } & \multicolumn{3}{|c|}{ Without trend } & \multicolumn{2}{|l|}{ With trend } \\
\hline & Statistic & Value & $p$-value & Value & $p$-value \\
\hline \multirow[t]{4}{*}{ Westerlund } & $G_{\mathrm{t}}$ & $-4.790 *$ & 0.000 & $-4.992 *$ & 0.000 \\
\hline & $G_{\mathrm{a}}$ & $-26.509 *$ & 0.000 & $-25.954^{*}$ & 0.000 \\
\hline & $P_{\mathrm{t}}$ & $-10.860 *$ & 0.000 & $-10.916^{*}$ & 0.000 \\
\hline & $P_{\mathrm{a}}$ & $-33.481^{*}$ & 0.000 & $-32.655^{*}$ & 0.000 \\
\hline
\end{tabular}

Note: * represents null hypothesis rejection of no cointegration at a $1 \%$ significance level for Westerlund estimates. For optimal lead and lag selection, we use AIC. 
Table 6: Summary Results of Heterogeneous Co-Integration Tests With breaks

\begin{tabular}{|c|c|c|c|c|c|}
\hline \multirow[t]{2}{*}{ Test type } & \multicolumn{3}{|c|}{$\begin{array}{c}\text { Without trend } \\
\text { Eight Leading African Economies }\end{array}$} & \multicolumn{2}{|l|}{ With trend } \\
\hline & Statistic & Value & $p$-value & Value & $p$-value \\
\hline \multirow[t]{4}{*}{ Westerlund } & $G_{\mathrm{t}}$ & $-4.542^{*}$ & 0.000 & $-4.659 *$ & 0.000 \\
\hline & $G_{\text {а }}$ & $-26.912 *$ & 0.000 & $-25.807 * *$ & 0.022 \\
\hline & $P_{\mathrm{t}}$ & $-12.445^{*}$ & 0.000 & $-12.617^{*}$ & 0.000 \\
\hline & $P_{\mathrm{a}}$ & $-25.376^{*}$ & 0.000 & $-24.829 *$ & 0.002 \\
\hline
\end{tabular}

Note: * and $* *$ represents null hypothesis rejection of no cointegration at $1 \%$ and $5 \%$ significance level for Westerlund estimates. For optimal lead and lag selection, we use AIC.

\section{Long-run and Short-run Estimate}

Table 7 shows the Long and Short-run findings of eight leading African countries. The square brackets contain the t-statistics. The coefficient of long-run relationships concerning $L F G U_{i t}$, $L F D I_{i t}$ and $L E G_{i t}$ are positive and significantly statistic at $1 \%$. Furthermore, the dummy variable concerning the global financial crises at both the long run and short-run coefficients are significant and negative. The variables sign goes in the same direction with the theoretical predictions.

Meanwhile, the coefficients for both $L F G U_{i t,} L F D I_{i t}$ and $L E G_{i t}$, in the long run, are positive and statistically significant at both $1 \%$, $5 \%$ and $10 \%$ level of significance. Whereas in the short run, both $L F G U_{i t,}$ and $L F D I_{i t}$ are having a negative and significant relationship to financial development, but $L E G_{i t}$ shows a positive and significant relationship to financial development. Going by the conclusion that financial globalisation is inevitable as its consequences can be avoided only at the detriment of the country's prosperity.

This study can attest that Fisher and Dornbush were somehow correct in their stands for pre $21^{\text {st }}$ century, in line with this, the study shows that these economies' took advantage of those uncertainties in elevating the conversion of locally assembled resources into lending for countries investors. Additionally, Kose et al. (2011) proposed that developing economies who were dependent on external capital are less (as a result of much mobilization reliance of local savings for investments) likely to have comparatively performed excellently than their match, and this can be affirmed with this study's findings.

Besides, theoretically, there must be a significant and negative sign for ect $t_{t-1 .}$ However, the result of this study shows that, the more the coefficient goes higher, the greater and stable the short-run relationship becomes. Furthermore, Banerjee et al. (1998) concluded that when the error correction term is strongly significant, it gives more room for the presence of stable longrun associations.

External capital flows may be a covering gain for local financial sector development, especially when considering surpluses in the financial institutions of these African countries. The findings here go with the fact that as these African economies are faced with global financial uncertainty, there is every likelihood that they will advance their local institutions to avoid risks attached to the pointed uncertainty.

Conversely, based on the result of this study, the global financial crises of 2007-2008 affected these eight leading African economies negatively. This is because the long and short- 
run coefficient shows a negative and significant probability value at a $1 \%$ level. Moreover, it is not far from the fact that financial sectors in Africa are less developed and therefore in their effort to develop their financial sectors, they tend to integrate with the rest of the world as such they seem more open to global financial shocks.

However, the findings recorded that in the long run, at a $1 \%$ increase in financial globalisation uncertainty, it will lead to a $0.192 \%$ increase in financial development, while in the short run, at a $1 \%$ decrease in financial globalisation uncertainty, it will result in $0.137 \%$ increase in financial development.

Therefore, these African countries tend to seize the advantage of improving their financial institutions and channelling the available surplus resources to various productive sectors of their economy to become more reliant on the domestic financing and subsequently get their respective financial sectors developed. This is not far from the International Monetary Fund (IMF) 2017 saying that African financial sectors are not developed even when access to the criteria that can be found in the developing countries.

\section{DH Causality}

The causality analysis in Table 8 highlights a bidirectional causality relationship between financial development and financial globalisation uncertainty, which implies that financial development and financial globalisation uncertainty are reinforcing one another in the eight leading African countries. It also depicts another bidirectional causal linkage between financial development and economic

Table 7: Pooled Mean Group Estimates without Interaction

Leading African Countries

\begin{tabular}{|c|c|c|c|}
\hline Variables & Coefficients & Standard error & $p$-value \\
\hline \multicolumn{4}{|c|}{ Long-run estimates } \\
\hline$L F G U_{i t}$ & $\begin{array}{l}0.192 * \\
{[9.631]}\end{array}$ & 0.019 & 0.000 \\
\hline$L F D I_{i t}$ & $\begin{array}{l}0.181 * \\
{[6.341]}\end{array}$ & 0.029 & 0.000 \\
\hline$L E G_{i t}$ & $\begin{array}{c}0.147^{*} \\
{[5.551]}\end{array}$ & 0.027 & 0.000 \\
\hline$T_{i t}$ & $\begin{array}{l}-0.455^{*} \\
{[-4.105]}\end{array}$ & 0.111 & 0.000 \\
\hline \multicolumn{4}{|c|}{ Short-run estimates } \\
\hline$\Delta L F G U_{i t}$ & $\begin{array}{l}-0.137^{*} \\
{[-6.417]}\end{array}$ & 0.021 & 0.000 \\
\hline$\Delta L F D I_{i t}$ & $\begin{array}{c}-0.110 * \\
{[-10.156]}\end{array}$ & 0.011 & 0.000 \\
\hline$\Delta L E G_{i t}$ & $\begin{array}{c}0.046^{*} \\
{[8.869]}\end{array}$ & 0.052 & 0.000 \\
\hline$T_{i t}$ & $\begin{array}{c}-0.513 \\
{[-7.568]}\end{array}$ & 0.068 & 0.000 \\
\hline$e c t_{t-1}$ & $\begin{array}{c}-0.611^{*} \\
{[-10.156]}\end{array}$ & 0.060 & 0.000 \\
\hline Optimal lag & & $(1,1,1,1,1)$ & \\
\hline
\end{tabular}


growth; this supported the finance theory of Schumpeter (1911) which claimed that finance leads to growth and Robinson (1952) argument that growth leads to finance.

Moreover, the results recorded a one-way causal relationship between foreign direct investment running to financial development, which means financial development does not cause foreign direct investment, but finance does. This is in line with the Dunning (1973) general paradigm theory which argued that advantages attached to the location of the accommodating nation are the driving factor of foreign direct investment inflows into the economy.

However, should there be foreign investors inflow, economic and financial activities will increase and subsequently leads to an increase in demand for financial services which will in return trigger the expansion of the economy's financial sector in order to meet up with the rising demand.

\section{Conclusion and Policy Recommendations}

The study focused on eight leading African countries, mainly, Egypt, Nigeria, South Africa, Algeria, Morocco, Ethiopia, Ghana and Kenya, for the period moving from 1970 to 2018 and analysed the effect of financial globalisation uncertainty on financial development, thereby including foreign direct investment and economic growth to support the model. The fact that the findings depict the long-run relationship test without breaks, a rejection of the null hypothesis of no co-integration at constant and $1 \%$ level of significance, shows it firmly rejects the null hypothesis and accepts the alternative hypothesis with regards to the presence of cointegration among variables under this study.

Similarly, at constant and trend, all the four statistics revealed rejection of the null hypothesis and firmly acceptance of co-integration among the variables. Also considering the global financial crises of 2007 down to 2018, the results revealed that at a constant level, there was a strong significant long-run relationship among variables with a $1 \%$ level of significance.

Table 8: The Result of DH panel causality Test Model

\begin{tabular}{llll}
\hline Hypothesis & W-Stat. & Zbar-Stat. & Prob. \\
\hline$L F G U_{i t} L F D_{i t}$ & 7.438 & 9.785 & 0.000 \\
$L F D_{i t} L F G U_{i t}$ & 2.69505 & 3.04123 & 0.002 \\
$L F D I_{i t} L F D_{i t}$ & 2.33571 & 2.37833 & 0.017 \\
$L F D_{i t} L F D I_{i t}$ & 0.96814 & -0.14457 & 0.885 \\
$L E G_{i t} L F D_{i t}$ & 1.89442 & 4.56423 & 0.000 \\
$L F D_{i t} L E G_{i t}$ & 1.7837 & 6.35997 & 0.000 \\
\hline
\end{tabular}

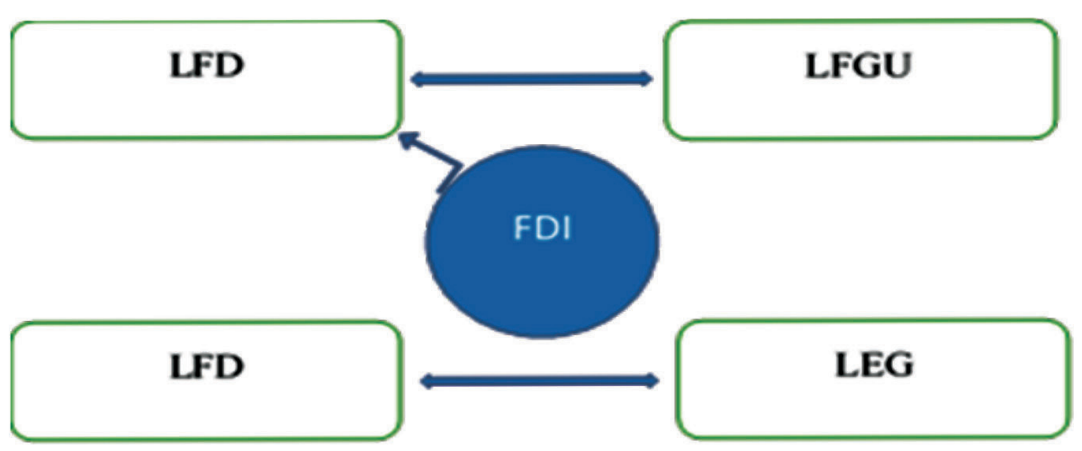

Figure 2 
Whereas, at constant and trend the group mean statistic rejects the null hypothesis at a 5\% significant level, while the panel statistic rejects the null hypothesis at a $1 \%$ level of significance.

However, as seen that financial globalisation uncertainty has a positive and significant long-run relationship and a short run negative relationship with financial development in these leading African countries, besides, the global financial crises show that it has a negative impact on financial development in both the long and short run. We further found a bidirectional causal relationship between financial globalisation uncertainty and financial development.

Thus, the current study concludes that financial globalisation is inevitable as its consequences can be avoided only at the detriment of the country's prosperity, this study can attest that Fisher and Dornbush were somehow correct in their stands for pre $21^{\text {st }}$ century, in line with this, the study shows that these economies took advantage of those uncertainties in elevating the conversion of locally assembled resources into lending for countries investors. Additionally, Kose et al. (2011) proposed that developing economies whose dependence on external capital was less (as a result of much mobilization reliance of local savings for investments) said to have comparatively performed excellently than their match, and this can be affirmed with this study's findings

Conversely, the current study shows that foreign direct investment and economic growth support financial development. This is a significant result in the ambiance of these eight leading African countries because these inflows can be channelled to investment projects identified to be productive, as such, increase economic activities; hence, economic growth and as demand for financial services will increase due to the growth, it will trigger financial sector development following (Robinson, 1952).

Therefore, that necessitates the need for the governments of these countries to come up with policies that will help their financial sector in terms of proper allocation of resources and be able to encourage savings and investments. Also, effort and necessary policies should be in place to attract foreign investors and encourage local productions in the economy through a formal financial system. With this, these African economies could be able to withstand any future shocks whether internal or external.

And given that financial globalisation uncertainty appears to be positively related to financial sector development of the sampled countries, follows that uncertainty in foreign capital flows may be a disguised advantage for domestic financial development, especially in dealing with the substantially documented issue of surplus liquidity in African financial institutions. As such, the stake holders need to continue devising means towards improving their respective financial system, thereby allowing them to work freely with less government intervention. This is because researchers have shown that most of these oil exporting countries' financial sectors are dominantly controlled by government, and that limits their efficiency (Farouq et al., 2020).

\section{Acknowledgements}

An appreciation goes to the Universiti Sultan Zainal Abidin for their support.

\section{References}

Abdulkadhim, H., \& Region, K. (2014). Financial Development, Trade Openness and Economic Growth: A Trilateral Financial Development, Trade Openness and Economic Growth: A Trilateral Analysis of Bahrain. (February 2016). https://doi.org/10.5539/ijef.v7n1p241

Siddique, H. M. A., \& Majeed, M. T. (2015). Energy consumption, economic growth, trade and financial development nexus in South Asia. Pakistan Journal of Commerce and Social Sciences (PJCSS), 9(2), 658682. 
Achamoh, V. N., \& Baye, F. M. (2016). Examination of the effects of public spending and trade policy on real exchange rate in Cameroon. EuroEconomica, 34(2).

Adeel-farooq, R. M. (2017). Trade openness, financial liberalisation and economic growth The case of Pakistan and India. 3(2), 229-246. https://doi.org/10.1108/ SAJBS-06-2016-0054

Ahmed, S. A. (2015). Analyzing economic development: What can we learn from remittances recipient countries ? LIU-IEIFIL-A--15/02037-SE 1-69

Aibai, A., Huang, X., Luo, Y., \& Peng, Y. (2019). Foreign direct investment, institutional quality, and financial development along the Belt and Road: An empirical investigation. Emerging Markets Finance and Trade, 3(8), 1-20. https://doi.org/10.1080/154049 6X.2018.1559139

Ajayi, M. A., \& Aluko, O. A. (2019). Testing the validity of the simultaneous openness hypothesis in Nigeria (1990 - 2015). 31(1), 58-70. https://doi.org/10.1111/14678268.12363

Akbas, Y. E. (2015). Financial development and economic growth in an emerging market: Bootstrap panel causality analysis. XXII(3), 171-186.

Ananzeh, I. E. N., \& Othman, M. D. (2019). Analyzing the effect of financial development on economic growth The Jordanian experience. Investment Management and Financial Innovations, 16(1), 119-127. https://doi.org/10.21511/ imfi.16(1).2019.09

Arif, I., \& Rawat, A. S. (2019). Trade \& financial openness and their impact on financial development evidence from South Asian economies. 16(6), 1-14. https://doi. org/10.1108/SAJBS-06-2018-0063

Asiedu, E. (2002). On the determinants of foreign direct investment to developing countries: Is Africa different. World development, 30(1), 107-119.
Asongu, S. A., \& De Moor, L. (2015). Financial globalisation and financial development in Africa: Assessing marginal, threshold and net effects (No. WP/15/040). AGDI Working Paper.

Asongu, S. A., Koomson, I., \& Tchamyou, V. S. (2017). Research in International Business and Finance Financial globalisation uncertainty/instability is good for financial development. Research in International Business and Finance, 41(August 2016), 280-291. https://doi.org/10.1016/j. ribaf.2017.04.042

Banerjee, A., Dolado, J., \& Mestre, R. (1998). Error $\square$ correction mechanism tests for co-integration in a single $\square$ equation framework. Journal of Time Series Analysis, 19(3), 267-283.

Bank for International Settlements. (2019). "BIS statistics explorer". http://stats.bis.org/ statx/toc/DER.html

Bank, W. (2017). Financial sector development in Africa - An overview. Financial Sector Development in Africa-An, 7(4), 1-5. https://doi.org/10.1016/j.rdf.2017.04.002

Bano, S., Zhao, Y., Ahmad, A., Wang, S., \& Liu, Y. (2019). Why did FDI inflows of Pakistan decline? From the perspective of terrorism, energy shortage, financial instability, and political instability. Why did FDI inflows of Pakistan decline? From the perspective of terrorism, energy shortage, financial. Emerging Markets Finance and Trade, 55(1), 90-104. https://doi.org/10.1080/154 0496X.2018.1504207

Benfratello, L., D'Ambrosio, A., \& Sangrigoli, A. (2019). International investment agreements and FDI inflows in Africa. Global Journal of Management and Business Research, 12(18), 85-97.

Boateng, E., Amponsah, M., \& Ã, C. A. B. (2017). Complementarity effect of financial development and FDI on investment in Sub-Saharan Africa: A panel data analysis. 29(2), 305-318. 
Bongini, P., Iwanicz-drozdowska, M., Smaga, P., \& Witkowski, B. (2017). Financial development and economic growth: The role of foreign-owned banks in CESEE countries. 2(2), 1-25. https://doi. org/10.3390/su9030335

Católica, C., \& Universidad, P. (2012). The impact of financial development trade on the economic growth of Bolvia Antonio N. Bojanic * I. Introduction. Journal of Applied Economics, 15(1), 51-70. https:// doi.org/10.1016/S1514-0326(12)60003-8

Costigan, J., \& Wong, M. C. S. (2016). The effect of financial sector development on FDI led growth in China. 177(5), 1-28.

Desbordes, R., \& Wei, S. J. (2017). The effects of financial development on foreign direct investment. Journal of Development Economics, 127(7), 153-168. https://doi. org/10.1016/j.jdeveco.2017.02.008

Donaubauer, J., Neumayer, E., \& Nunnenkamp, P. (2016). Promoting FDI through financial market development in host and source countries. International Growth Centre Blog, 1(1), 4-7.

Dumitrescu, E., \& Hurlin, C. (2012). Testing for Granger non-causality in heterogeneous panels. Econ Model, 29, 1450-1460. https:// doi.org/ 10.1016/j.econmod.2012.02.014

Dunning, J. H. (1973). The determinants of international production. Oxford Economic Papers, 25(3), 289-336.

Elkhuizen, L., Hermes, N., Jacobs, J., \& Meesters, A. (2018). Financial development, financial liberalisation and social capital. Applied Economics, 50(11), 1268-1288. https://doi. org/10.1080/00036846.2017.1358446

Maasoumi, E., Heshmati, A., Wan, G., Batuo, M. E., \& Asongu, S. A. (2015). The impact of liberalisation policies on income inequality in African countries. Journal of Economic Studies: MPRA Paper No. 43344, posted 20 Dec 2015 16:58 UTC

Fan, J. J., Xu, R., Su, C. W., \& Shi, Q. H. (2018). Demand-following or supply-leading?
Trade openness and financial development in China. Journal of International Trade and Economic Development, 27(3), 314332. https://doi.org/10.1080/09638199.201 7.1390779

Farouq, I., Sulong, Z., Ahmad, U., Jakada, A., \& Sambo, N. (2020). Heterogeneous Data Approach on financial development of selected African leading economies. Data in Brief, 105670.

Fetai, B. (2015). Financial integration and financial development: Does financial integration metter? European Research Studies, 18(2), 97.

Friedman, M. (1937). The use of ranks to avoid the assumption of normality implicit in the analysis of variance. Journal of the American Statistical Association, 32(200), 675-701.

Gokmenoglu, K. K., \& Amin, Y. (2015). The relationship among international trade, financial development and economic growth: The case of Pakistan. Procedia Economics and Finance, 25(3), 489$496 . \quad$ https://doi.org/10.1016/S22125671(15)00761-3

Gow, J. (2015). The effects of Internet usage, financial development and trade openness on economic growth in South Africa: A time series analysis and. Telematics and Informatics, 6(3), 1-38. https://doi. org/10.1016/j.tele.2015.11.006

Granger, C. W. (1969). Prediction with a generalized cost of error function. Journal of the Operational Research Society, 20(2), 199-207.

Gural, A., \& Lomachynska, I. (2017). FDI and financial development as determinants of economic growth for V4 countries. 3(4), 59-64.

Hakimah, N., Mohd, H., Ripain, N., Ahmad, N. W., Islam, K., \& Selangor, A. (2015). Financial development and FDI-Growth nexus. 25(2), 435-446. 
Iheanacho, E. (2016). The impact of financial development on economic growth in Nigeria: An ARDL Analysis. 4(2), 1-12. https://doi.org/10.3390/economies4040026

IMF. (2019). IMF Standing Borrowing Arrangements. IMF Factsheet as of September 2019. http://www.imf.org/ external/np/exr/facts/pdf/gabnab.pdf [Accessed 3 April 2019]

Jamel, L., \& Maktouf, S. (2017a). The nexus between economic growth, financial development, trade openness, and $\mathrm{CO} 2$ emissions in European countries. Cogent Economics \& Finance, 86(4), 1-25. https:// doi.org/10.1080/23322039.2017.1341456

Jamel, L., \& Maktouf, S. (2017b). The nexus between economic growth, financial development, trade openness, and $\mathrm{CO} 2$ emissions in European countries. Cogent Economics \& Finance, 86(5), 1-25. https:// doi.org/10.1080/23322039.2017.1341456

Kassi, D., Nasiri, A., \& Edjoukou, A. J. R. (2017). Financial development, economic growth and energy consumption Nexus in Cote d'Ivoire. International Journal of Finance \& Banking Studies (21474486), 6(3), 1-21.

Kaushal, L. A., \& Pathak, N. (2015). The causal relationship among economic growth, financial development and trade openness in Indian economy. International Journal of Economic Perspectives, 9(2), 5-22.

Kose, M. A., Prasad, E. S., \& Taylor, A. D. (2011), "Threshold in the process of international financial integration". Journal of International Money and Finance, 30(1), 147-179.

Kouki, I. (2018). Financial development and economic growth in the North African Region. African Development Review, 25(4), 551-562. https://doi. org/10.1111/1467-8268.12049

Lawal, A. I., Nwanji, T. I., Ashley, A., \& Ahmed, V. (2016a). Economic growth, financial development and trade openness in Nigeria:
An application of the ARDL bound testing approach. Cogent Economics and Finance, 4(1), 1-15. https://doi.org/10.1080/2332203 9.2016.1258810

Lawal, A. I., Nwanji, T. I., Ashley, A., \& Ahmed, V. (2016b). Economic growth, financial development, and trade openness in Nigeria: An application of the ARDL bound testing approach. Cogent Economics \& Finance, 12(4), 1-15. https://doi.org/10.1 080/23322039.2016.1258810

Le, T., Kim, J., Lee, M., Le, T., Kim, J., \& Lee, M. (2016). Institutional quality, trade openness, and financial sector development in Asia: An empirical investigation. 6(5), 1-13. $\quad$ https://doi.org/10.1080/154049 6X.2015.1103138

Lee, C., Chang, C., \& Lee, C. (2019). FDI, Financial Development, and Economic Growth: International Evidence. Growth : International Evidence, 0326(4), 1-24. https://doi.org/10.1016/S15140326(09)60015-5

Levin, A., Lin, C. F., \& Chu, C. S. J. (2002). Unit root tests in panel data: Asymptotic and finite-sample properties. Journal of Econometrics, 108(1), 1-24.

Li, S., Zhang, J., \& Ma, Y. (2015). Commercial development, environmental quality, and economic growth. Sustainability (Switzerland), 7(7), 9395-9416. https://doi. org/10.3390/su7079395

Makoni, P. Lindelwa. R. (2016). The role of financial market development in foreign direct investment and foreign portfolio investment in selected African economies (Doctoral dissertation). 577649 PhD_thesis_29_November_2016_final.pd $\bar{f}$

Robert, L. (1988). On the mechanics of economic development. Journal of Monetary Economics.

Majeed, M. T., \& Malik, A. (2016). E-government, financial development and economic growth. Pakistan Journal of Applied Economics, 26(2), 107-128. 
Karimu, A., \& Marbuah, G. (2017). Reexamining the financial developmentopenness nexus: Nonparametric evidence for developing countries. Journal of Applied Economics, 20(2), 373-394.

Masamba, K. (2017). An analysis of the impact of foreign direct investment on the banking sector in South Africa (Doctoral dissertation, University of Cape Town).

Maasoumi, E., Heshmati, A., Wan, G., Batuo, M. E., \& Asongu, S. A. (2015). The impact of liberalisation policies on income inequality in African countries. Journal of Economic Studies.

Mazin, N., \& Rahmdzey, M. (2016). Resilient growth strategies: The role of trade openness and financial depth. 1(2), 102-117.

Milena lipovina-božovic and julija cerovi 'csmolovic. (2016). And Financial Development. 11(4), 349-365.

Munemo, J. (2017). Foreign direct investment and business start-up in developing countries: The role of financial market development. Quarterly Review of Economics and Finance, 65(5), 97-106. https://doi.org/10.1016/j.qref.2016.08.010

Munemo, J. (2018). Entrepreneurial success in Africa: How relevant is a foreign direct investment and financial development? African Development Review, 30(4), 372-385. https://doi.org/10.1111/14678268.12345

Muranovic, Z. (2018). Does the local financial market enhance the effect of foreign direct investments? A study on developing countries.

Naz, S., Sultan, R., Zaman, K., Aldakhil, A. M., Nassani, A. A., \& Abro, M. M. Q. (2019). Moderating and mediating role of renewable energy consumption, FDI inflows, and economic growth on carbon dioxide emissions: Evidence from the robust least square estimator. Environmental Science and Pollution Research, 26(3), 2806-2819. https://doi.org/10.1007/s11356-018-3837-6
Ndako, U. B. (2010). Stock markets, banks and economic growth: Time series evidence from South Africa. African Finance Journal, 12(2), 72-92.

Omri, A., Daly, S., Rault, C., \& Chaibi, A. (2015). Commercial development, environmental quality, trade and economic growth: What causes what in MENA countries $\square$. Energy Economics, 48(2), 242-252. https://doi. org/10.1016/j.eneco.2015.01.008

Onanuga, O. T. (2016). Do financial and trade openness lead to financial sector development in Nigeria? 19(2), 57-68. https://doi.org/10.1515/zireb-2016-0008

Otchere, I., Senbet, L., \& Simbanegavi, W. (2017). Financial sector development in Africa-an overview. Review of Development Finance, 7(1), 1-5.https://doi.org/10.1016/j. rdf.2017.04.002

Pan, X., Uddin, K., Han, C., \& Pan, X. (2018). Dynamics of financial development, trade openness, technological innovation, and energy intensity: Evidence from Bangladesh. Energy, 5(7), 1-24. https://doi. org/10.1016/j.energy.2018.12.200

Parks, P. (2018). Foreign direct investment and industrialization in Sub-Saharan. 2(10551274), 1-67.

Personal, M., Archive, R., Batuo, E., Mlambo, K., \& Asongu, S. (2017). Mp r a. (82641).

Pervez, P., \& Nasreen, S. (2017). Financial development, financial liberalization, and Institutions Nexus in selected Sample of Middle-Income Countries. 1(12), 1-38.

Pesaran, M. H. (2007). A simple panel unit root test in the presence of cross $\square$ section dependence. Journal of Applied Econometrics, 22(2), 265-312.

Pesaran, M. H., \& Smith, R. (1995). Estimating long-run relationships from dynamic heterogeneous panels. Journal of Econometrics, 68(1), 79-113.

Pesaran, M. H., Shin, Y., \& Smith, R. P. (1999). Pooled mean group estimation of dynamic 
heterogeneous panels. Journal of the American Statistical Association, 94(446), 621-634.

Pradhan, R. P., Arvin, M. B., Hall, J. H., \& Nair, M. (2017). Trade openness, foreign direct investment, and finance-growth nexus in the Eurozone countries. Journal of International Trade and Economic Development, 26(3), 336-360. https://doi.or $\mathrm{g} / 10.1080 / 09638199.2016 .1249392$

Rahman, M. M., Shahbaz, M., \& Farooq, A. (2015). Financial development, international trade, and economic growth in Australia : New evidence from Multivariate Framework Analysis. 16(1), 37-41. https:// doi.org/10.1080/10599231.2015.997625

Rateiwa, R., \& Aziakpono, M. J. (2017). Non-bank financial institutions and economic growth: Evidence from Africa's three largest economies. South African Journal of Economic and Management Sciences, 20(1), 1-11.

Retina, R. (2017). Non-bank financial institutions and economic growth: Evidence from Africa' $\mathrm{s}$ three largest economies. 3(7), 1-11.

Robinson, J. (1952) The generalization of the general theory. In The Rate of Interest and Other Essays. MacMillan, London

Romer, P. M. (1986). Increasing returns and long-run growth. Journal of Political Economy, 94(5), 1002-1037.

Saidi, K. (2018). Foreign direct investment, financial development, and their impact on the GDP growth in Low- income Countries impact on the GDP Growth in Low-income Countries. International Economic Journal, 2(3), 1-15. https://doi.org/10.1080/1016873 7.2018 .1529813

Saini, N., \& Singhania M. (2018). Article information. Economic Studies, 45(2), 348382.

Sainz-Fernandez, I., Torre-olmo, B., Carlos, L., \& Sanfilippo-azofra, S. (2018). Development of the Financial Sector and
Growth of Microfinance Institutions: The Moderating Effect of Economic Growth. 5-7. https://doi.org/10.3390/su10113930

Salahuddin, M., Alam, K., Ozturk, I., \& Sohag, K. (2017). The effects of electricity consumption, economic growth, financial development and foreign direct investment on CO 2 emissions in Kuwait. Renewable and Sustainable Energy Reviews, 3(1), 1-9. https://doi.org/10.1016/j.rser.2017.06.009

Sare, Y. A. (2019). Studies on financial sector development and international trade in Africa.

Schumpeter, J. (1911). The theory of economic development. Harvard Economic Studies, XLVI.

Shah, I., Abidin, Z., Haseeb, M., Azam, M., \& Islam, R. (2015). Foreign direct investment, financial development, international trade and energy consumption: Panel data evidence from selected ASEAN countries. 5(3), 841-850.

Shah, M. H. (2017). Economic development and foreign direct investment: The case of the Middle East and North African (MENA) developing nations. 2(82013), 1-18.

Sirag, Ahmed, A. (2018). Economic development, FDI and economic growth: Evidence from Sudan. 45(8), 1236-1249. https://doi.org/10.1108/IJSE-10-2017-0476

Soumare, I., \& Tchana, F. T. (2015). Causality between FDI and Financial Market Development: Evidence from emerging markets. 29(2), 205-216. https://doi. org/10.1093/wber/lhv015

Susanti, N. (2018). Does the financial sector affect economic development in ASEAN during 2010-2016? XXV(4), 205-220.

Tsaurai, K. (2017a). Investigating the relationship between financial development, trade openness and economic growth in Argentina: A multivariate causality framework 2. Review of Related Literature, 13(3), 39-55. 
Tsaurai, K. (2017b). The impact of financial sector development on foreign direct investment in emerging markets.

Tsaurai. (2018). Complementarity between foreign aid and financial development as a driver of economic growth in selected emerging markets. 21(4), 46-61.

Viana, R., Kedong, Y., \& Xuemei, L. (2017). The relationship between FDI, economic growth and financial development in Cabo Verde. 9(5), 132-142. https://doi.org/10.5539/ijef. v9n5p132

Wang, Y., \& Ntim, C. G. (2015). Financial development and economic growth in China”. 12(3), 1-18.

Wasiaturrahma1, Ramses Muhammad Rizal2, Shochrul Rohmatul, A. (2019). Financial deepening and economic growth in Indonesia. 14(1), 24-32.

Wei, W. (2017). FDI outflows, exports, and financial development. Journal of Economic Studies, 44(6), 987-1003. https:// doi.org/10.1108/JES-01-2017-0020

Westerlund, J., \& Edgerton, D. L. (2008). A simple test for cointegration in dependent panels with structural breaks. Oxford Bulletin of Economics and Statistics, 70(5), 665-704.

Williams, K. (2018). Has the finance-growth link been broken? Panel data evidence from Latin America and the Caribbean. Economia, 19(3), 404-423. https://doi. org/10.1016/j.econ.2018.10.001

Word Bank (2019). "World Development Indicators', World Bank Publications http:// www.gopa.de/fr/news/world-bank-release- world-development-indicators-2019 (Accessed: 25/04/2019)

World Bank Group. (2017). World development indicators 2017. World Bank.

World Bank. (2015). World development report 2015: Mind, society, and behavior.

Yakubu, A. S., Aboagye, A. Q. Q., Mensah, Lord, \& Bokpin, G. A. (2018). Effect of financial development on international trade in Africa: Does the measure of finance matter? Journal of International Trade and Economic Development, 27(8), 917-936. https://doi.org/10.1080/09638199.2018.14 74246

Hosseininasab, E., Yavari, K., Afzali Abarguee, V., \& Basakha, M. (2012). Effects of trade and financial liberalisation on financial development (Case study: MENA Countries). International Economics Studies, 40(1), 57-66.

Yourougou, P., Otchere, I., \& Soumare, I. (2016). FDI and financial market development. 3(3), 651-678. https://doi.org/10.1111/ twec. 12277

Zare, M., \& Haghighat, A. (2017). The effect of financial liberalisation on financial development in Iran. 7(3), 131-142. https:// doi.org/10.5923/j.economics.20170703.04

Zhang, C., Zhu, Y., \& Lu, Z. (2015). Trade openness, financial openness, and financial development in China. Journal of International Money and Finance, 15(4), 1-37. https://doi.org/10.1016/j. jimonfin.2015.07.010

\section{ORCID}

Ibrahim Sambo Farouq ${ }^{\text {ID }}$ https://orcid.org/00000002-3731-5861 